\title{
EBRIOS, VAGOS Y ANALFABETOS. EL SUFRAGIO RESTRINGIDO EN BOLIVIA, 1826-1952 (*)
}

POR

MARTA IRUROZQUI

CSIC

Madrid

Este texto analiza los motivos y las estrategias de los sectores populares bolivianos, artesanos mestizos y campesinos indigenas, destinados a lograr existencia social y presencia pública y politica en un régimen electoral censitario (1826-1952). Para ser considerados ciudadanos no pidieron la ampliación del sufragio, sino que demostraron tener las cualidades exigidas en un sistema de voto "letrado", recurriendo tanto a la ambigüedad de la ley, como a la retórica politica dominante que hacía inseparables educación y ciudadanía.

Tras la Independencia, la creación de un poder soberano estuvo vinculada a la nueva legitimidad política procedente de la

Sigla UTILIZADA:

ADLP. Archivo Departamental de La Paz.

${ }^{*}$ ) Este texto pertenece al Proyecto I+D SEC94-0196 financiado por el Ministerio de Educación y Ciencia. Muchas de las afirmaciones han sido resultado de las discusiones mantenidas con Víctor Peralta, Luís Miguel García Mora, Marisa González de Oleaga, Sonia Alda y los alumnos del curso de doctorado "Partidos políticos y elecciones en América Latina, 1830-1930» impartido por Carlos Malamud en el Instituto Universitario Ortega y Gasset. 
instauración de los regímenes republicanos, que fueron la condición necesaria para la transferencia del poder de la Corona a las elites criollas (1). Esa especificidad de las democracias latinoamericanas explica tanto la precocidad de sus instituciones democráticas, como la ambigüedad que desde un comienzo va a establecerse entre el texto constitucional como principio de legalidad y la vida política. Si bien "pueblo» y elección eran términos de un proyecto de renovación que daba a los 'sectores dominantes fórmulas de reemplazo del orden colonial que evitaran la anarquía o a la disolución política, esto es, el ocaso de su poder y prestigio, era importante que no provocaran una fractura irremediable con costumbres políticas que gozaban del beneficio de la tradición. Eso llevó a la búsqueda de formas prescriptivas que conciliaran la desigualdad del antiguo régimen con los principios igualitarios emergentes. Era necesario encontrar una solución institucional que tradujese el conjunto de intereses y valores en una creencia compartida, en un principio de legitimidad, que no sólo buscase satisfacer ciertas ideas acerca del régimen mejor adaptado a una doctrina de libertad, sino también gratificar intereses materiales reivindicados por grupos sociales (2).

Esto evidenciaba que el sistema creado por los contemporáneos no estaba necesariamente destinado a dar poder al pueblo, ni a construir un régimen representativo tal como lo concebimos ahora-dedicado a reflejar la heterogeneidad social y a arbitrar pacíficamente las diferencias o los conflictos resultados de la diversidad de intereses y opiniones-. Buscaba configurar una comunidad política igualitaria y soberana, una nueva sociedad regida por nuevos principios que se expresase por medio de una asamblea, que haciendo las veces de la naciớn emitiera su voluntad y obrase por el interés general (3). Como eso no

(1) Pilar González Bernaldo, "Los clubes electorales durante la secesión del Estado de Buenos Aires (1852-1861): la articulación de dos lógicas de representación política en el seno de la esfera pública porteña», en el Coloquio Internacional "The Expansion of Citizenship in Latin America», Colombia, 1995 (versión preliminar), pág. 1.

(2) Natalio Botana, El orden conservador. La política argentina entre 1880 y 1916, Buenos Aires, ed. Sudamericana, 1985, págs. 41-43.

(3) François Xavier GUERRA, «El soberano y su reino. Reflexiones sobre la génesis del ciudadano en América Latina» en el Coloquio Internacional 
significaba reconocer que cualquier individuo tenía la capacidad y la formación para participar de modo activo y político en la comunidad recién creada, la cuestión siguiente fue establecer las fronteras que encuadraban esa entidad llamada pueblo, quiénes lo componían y quiénes debían permanecer marginados de él. En respuesta se dieron dos opciones: primera, el gobierno democrático era obra de un reducido grupo de personas selectas y sólo ellas integraban el pueblo donde residía el poder electoral; segunda, ese conjunto de individuos tendía a universalizarse abarcando un número cada vez más amplio de miembros (4). La primera posibilidad correspondía a un régimen censitario que asignaba a pocos la virtud de elegir y a la muchedumbre la ignorancia de no saber hacerlo, lo que implicaba que la calidad de los elegidos dependía de la de los electores. Desde la Constitución de 1839 hasta la Revolución de 1952 (5) ese fue el tipo de sufragio presente en Bolivia: directo (6), masculino, censitario y alfabeto.

Al contrario de lo ocurrido en otros países andinos, como Chile, Perú y Ecuador (7), no hubo ninguna reforma electoral

"The Expansion of Citizenship in Latin America», Colombia, 1995 (versión preliminar), pág. 9 .

(4) Botana [2], pág. 51.

(5) El voto universal se practica desde 1956, a pesar de que la Constitución vigente hasta entonces, la de 1947, no contemplaba ese punto, el primer texto constitucional que introduce el voto universal es el de 1961.

(6) Aunque el voto directo ha sido el favorito en las constituciones bolivianas, las tres primeras, la de 1826, promulgada por Antonio José de Sucre y las de 1831 y 1834, promulgadas por Andrés de Santa Cruz, contemplan el voto indirecto. De hecho, las elecciones de 1828, 1829 y 1831 fueron realizadas por el Congreso, mientras que la de 1835 fue la primera en la que el sufragante depositaba su confianza en las Juntas Electorales de Parroquia que emitían el voto (Marcelo GALINDO DE UGARTE, Constituciones bolivianas comparadas, 1826-1967, La Paz, ed. Los Amigos del libro, 1991, pág. 626). Ya con voto directo, aunque "letrado" o "calificado" fueron los veinticuatro comicios que van desde 1844 a 1951 (Carlos Mesa GisBert, Presidentes de Bolivia: entre urnas y fusiles, La Paz, ed. Gisbert y Cía., 1983, págs. 101-104).

(7) En Chile la ley de reforma electoral de 1874 estableció el sufragio universal masculino y alfabeto, lo que abrió el camino al desarrollo de partidos que buscaron representar todos los segmentos principales de la comunidad nacional (J. Samuel VAlenzuela, Democratización via reforma: La expansión del sufragio en Chile, Buenos Aires, ediciones del IDES, 1985). En Perú, la Ley de Reforma Electoral de 1896 excluyó a la población indígena campesina 
que marcase una ruptura de carácter participativo o representativo en el acontecer político. Durante este período, los reglamentos fueron semejantes en cuanto a las nociones de exclusión-inclusión ciudadana. El Decreto del 9 de febrero de 1925 dictado por Sucre fijó que para ser elector era necesario ser ciudadano en ejercicio, natural o vecino del partido con un año de residencia y con reputación de honradez y buena conducta (8). En la Constitución Bolivariana del 19 de noviembre de 1926, sólo cumplían el requisito de ciudadanía aquéllos que sabían escribir y leer y tenían algún empleo o industria, o profesaban una ciencia o arte sin sujección a otro en clase de sirviente doméstico. La diferencia de esta definición frente a las que aparecieron desde 1836 residía en que la condición de alfabeto sólo se exigía desde ese año (9), aunque hasta la Constitución de 1861 no reapareció tal requisito (10). El hecho de que las leyes electorales mencionadas pospusieran el ser alfabeto hasta una determinada fecha indica que calculaban que para esa época estaría resuelto el problema de educación en los sectores populares; no se olvide que la generalización de la instrucción primaria formaba parte del ideario liberal y que a través de ella se produciría una expansión natural de la ciudadanía. En 1877, se mantuvieron las mismas nociones de ciudadanía, fijándose el valor de la renta de la propiedad territorial

serrana de la participación en los comicios y dio a la costa la hegemonía política del país (G. CHIARAmonTI, "Andes o nación: la reforma electoral de 1896 en Perú", en Antonio Annino [coord.], Historia de las elecciones en Iberoamérica, siglo XIX, Buenos Aires, FCE, 1995; en especial, Jorge BASADRE, Elecciones y centralismo en el Perú (Apuntes para esquema histórico), Lima, Univ. del Pacífico, 1980). En Ecuador, el voto censitario se estableció con la Constitución Grancolombiana de 1821 y 1830 , refrendada en la primera constitución de la república ecuatoriana de 1835 , instaurándose en 1861 el sufragio universal masculino y alfabeto (Boletín electoral Latinoamericano, núm. VII. ILDISCAPEL, 1992, Malcon DEAS, "Venezuela, Colombia, Ecuador» en Leslie BETHELL, Historia de América Latina, vol. 6, Barcelona, Crítica, 1991, pág. 179).

(8) Edgar VALVERDE CASTAÑos, "Legislación electoral en Bolivia» en Legislación electoral comparada. Costa Rica, ed. EDUCA, 1988, págs. 51-52.

(9) Constitución de la República boliviana. Impresa e $e_{1}$ Chuquisaca en 25. de noviembre de 1826 por Fermín Arébalo en J. B. Pentland, Informe sobre Bolivia, 1826, Potosí, Banco Central de Bolivia, 1975.

(10) Galindo DE UgarTe [6], pág. 106. 
o de la industria o profesión en $16 \$$ mensuales que no proveniesen de la retribución de servicios prestados en calidad de doméstico (11), lo que se concretó en 1878 en $200 \$$ anuales (12). En 1908, por primera vez no se hizo explícita la necesidad de no ser doméstico para poder sufragar, aunque ello sí constaba en la Constitución de 1880 (13). De hecho, en la de 1938 el requisito de ocupación y renta desapareció momentáneamente (14), volviendo a estar presente en los reglamentos de 1940 y 1942.

De la persistencia del voto «cualificado» o «letrado» se infiere una voluntad explícita por parte de los legisladores bolivianos de construir una nación «moral» con ciudadanía limitada a través del diseño de un voto alfabeto, sujeto a propiedad y a bienes no provenientes del trabajo como doméstico. Esta república restrictiva apostaba por el juicio y la prudencia de los notables para ejercer la libertad política, ya que se les consideraba más capacitados para no caer en el vicio de la embriaguez, vagancia y comportamiento indecente. En virtud de su educación, riqueza, poder y prestigio, se les consideraba individuos responsables, capaces no sólo de ejercer con sabiduría el derecho de sufragio, sino también de actuar como árbitros de un futuro proceso de ampliación ciudadana a través de una reforma de la educación. De ahí que las diferencias entre los reglamentos electorales obedecieran, entonces, a un esfuerzo de matizar formalmente aquellos elementos que podían poner en duda la limpieza y seriedad de los comicios y afectar al desenvolvimiento formal de los partidos. Los temas enumerados se referían a la organización de los registros cívicos, a la fijación de fechas para realizar los diversos actos electorales, a la composición de los jurados, al funcionamiento de las mesas calificadoras, receptoras y computadoras, a la forma de llevar a cabo el escrutinio de los votos, a los requisitos que debían cumplir

(11) Reglamento de elecciones de Bolivia, La Paz, Imprenta de la Unión Americana, 1877.

(12) Reglamento electoral de Bolivia, Imp. La Paz, El Progreso, 1878.

(13) Reglamento electoral de la República de Bolivia, La Paz, Imp. La Prensa, 1908 .

(14) Galindo DE UGARTE [6], pág. 108. 
los votantes y los candidatos a munícipes, diputados y senadores, al reparto territorial de los mismos, a las garantías electorales y a las sanciones. Esa ausencia de reformas electorales que modificaran sustancialmente el número de participantes en los comicios contrastaba con las continuas denuncias de que los votantes no cumplían los requisitos para hacerlo, esto es, de que existía una porción significativa de población que sufragaba ilegalmente. A este hecho se unió la falta de los debates políticos y literarios de peticiones de ampliación de la ciudadanía, tanto por parte de los diputados, como por parte de los grupos excluidos del voto.

Ante esa situación cabe una pregunta: ¿cómo era posible ampliar el número de ciudadanos sin modificar los reglamentos electorales? La respuesta remite a la doble dimensión, legal e ilegal, de las elecciones; lo que incide en algunos aspectos fundamentales de la construcción del orden político en el período republicano: la ambigüedad y la imprecisión en la lectura e interpretación de la legislación y la distancia que existe entre la intención inicial dada a una normativa y el uso posterior que se hace de la misma. Este planteamiento conduce, a su vez, al tema de las transgresiones y de las modificaciones promovidas por los excluidos en un sistema electoral censitario. El término transgresión hace mención al aspecto de ilegalidad o informalidad que subyace en una elección, mientras que la palabra modificaciones se refiere a los deseos expresados por determinados sectores populares de acceder a la ciudadanía y a sus ventajas. Aunque en este texto sólo se analizará con detenimiento la segunda cuestión, es importante señalar lo básico del tema de la transgresión para comprender el proceso de apropiación de cultura política por parte de aquellos colectivos excluidos de la ciudadanía. Pese a las restricciones electorales, desde muy temprano los miembros de las Uniones Obrera y Artesana y los colonos de hacienda fueron votantes, formaron las mazorcas de matones, acudieron a los mítines, homenajearon a los candidatos y participaron en sus organizaciones. En todas las descripciones de los comicios, los encarcelados, los apaleados, los que vitoreaban y los que se emborrachaban eran siempre artesanos, obreros, mineros y peones de hacienda y eso sucedió gracias a la omnipresencia y

R. I., 1996, n.o 208 
generalización del fraude y de la violencia como prácticas compartidas por el gobierno y la oposición (15).

Respecto al segundo punto, en la documentación manejada no se han encontrado textos en los que los distintos actores sociales pidan la derogación de las medidas electorales restrictivas que producen exclusión; tampoco se conocen por parte de los sectores populares proyectos políticos alternativos a los tradicionales y dominantes en la esfera política de la época. Aunque de ese vacío no se puede inferir automáticamente la inexistencia de propuestas políticas populares, se puede pensar que sus manifestaciones tenían otro sentido y pretensiones más acordes con el modo en que percibían su entorno y las posibilidades de modificación del mismo a su favor. Esa sospecha se acrecienta al constatarse la existencia de demandas populares de admisión a la ciudadanía y no de ampliación de ésta, es decir, peticiones que no pretenden modificar los reglamentos, sino que buscan la oportunidad de demostrar poseer los atributos necesarios para estar dentro de dicha normativa restrictiva electoral. A pesar de la subordinación social de los sectores populares a las normas y decretos del Estado y a la autoridad y poder de las elites, compartían el lenguaje político, religioso y social del momento y no podían evitar el verse influidos por los ideales proclamados por el régimen político existente, incluso cuando se oponían a los patronos o al Estado, su oposición se expresaba en términos que sus oponentes podían comprender. Sus pensamientos, ideales y juicios nunca fueron una simple recapitulación a nivel inferior de los valores sancionados por el Estado y las clases dominantes, ni tampoco una negación de éstos, fueron resultado de sus experiencias, necesidades, percepción del lugar que ocupaban en el universo social y de lo que podían modificar en él, y de las pautas cambiantes de la sociedad en general. El hecho, entonces, de que empleasen y secundaran el proyecto político "civilizador» no significaba que en un primer momento lo interpretaran en los términos y en

(15) Ese tema está tratado en Marta IRuRozQui, «iQué vienen los mazorqueros! Usos y abusos del fraude y la violencia electorales en las elecciones bolivianas, 1914-1925», ponencia presentada al Coloquio Internacional The Expansion of Citizenship in Latin America , Colombia, 1995. 
las versiones que lo entendía la elite (16). Lo utilizaron porque necesitaban defender sus posibilidades de ascenso social con las armas de legalidad que la sociedad imponía ahora como correctas, luego aprendieron a luchar en un mundo nuevo con los instrumentos y reglas de éste. Al hacerlo, interiorizaron la norma, pero también asumieron el valor de ésta y la parte de la misma que podía beneficiarles y ayudarles a reivindicar lo que pensaban que les correspondía.

A partir de esta hipótesis, nos centraremos en el estudio de dos cuestiones interrelacionadas. Mientras la primera se refiere a por qué el régimen electoral censitario no tuvo detractores ni entre los miembros de la elite ni entre los sectores populares, la segunda profundiza en las estrategias que este grupo desarrolló para ser incluido en los requisitos de ciudadanía vigentes. Estos aspectos se estructurarán a través de la ambigüedad en la interpretación y aplicación de las leyes; lo que remite al hecho de que con el régimen republicano los sectores populares, artesanos urbanos y campesinos indígenas, entablaron luchas cotidianas por su existencia social recurriendo a la retórica política dominante que hacía inseparables educación y ciudadanía. Aunque por ahora no se dispone de una secuencia completa de documentación sobre el tema, se va a tratar de mostrar cómo la educación se entendió como un principio de igualdad que dotaba a la persona del estatus social necesario, la ciudadanía, para exigir al Estado la defensa de intereses tanto individuales como corporativos. Ese comportamiento les su-

(16) Sobre la homogeneidad de la elite a la hora de asumir los principios de modernidad política habría que matizar mucho y darse cuenta que quizá polarizar el comportamiento de las elites y de los populares en términos de conflicto y oposición, de modernidad y tradición sea un error que no nos permite entender las variables interpretativas, ni los usos y recreaciones que la población hizo a su favor de instituciones y corporaciones antiguas, a lo largo del siglo XIX (François-Xavier Guerra, Modernidad e Independencias. Ensayos sobre las revoluciones hispánicas, México, FCE-Mapre, 1992). La forma en que los sectores populares respondieron a los nuevos problemas no estaba determinada solamente por las características del nuevo sistema. Sus respuestas estuvieron también conformadas por valores, supuestos, prácticas, expectativas y sentimientos preexistentes. Fueron éstas las que les permitieron reelaborar el lenguaje de la revolución para adaptarlo a sus fines. 
puso un aprendizaje de la práctica política democrática, convirtiéndoles a la larga en ciudadanos de hecho y por derecho.

\section{1. «LA PLEBE EN ACCIÓN»}

En un texto sobre el comportamiento público de los artesanos urbanos de La Paz durante el gobierno de Isidoro Belzu (1845-1855), Rossana Barragán señala que se daba importancia a la educación en tanto permitía acceder a la ciudadanía, de ahí que sus demandas se sintetizaron en "Pan, instrucción y moralidad». Pero la educación no era únicamente un modo de negar el analfabetismo, era «un índice de valor polisémico, un nudo simbólico de múltiples significados asociado a las clases altas, al poder de la escritura, al estatus y al reconocimiento social»; es decir, que era una de las pocas vías que permitía el ascenso y la movilidad social, lo que explica que fuera un elemento en torno al que condensaron los conflictos sociales, étnicos y políticos. Tras la demanda de ciudadanía había algo más que una simple respuesta de reacción a las condiciones surgidas a partir de las primeras constituciones. Estar incluidos en ella permitía a los artesanos luchar contra la atribución de características y clichés étnicos basados en la organización social colonial por castas y estamentos, y, por tanto, situar la causa de la diferenciación social en la educación y no en el nacimiento. Si la primera marcaba la diferencia podía esperarse, a través de su adquisición, una igualdad por encima de las diferenciaciones étnicas y estamentales y, en consecuencia, una mayor movilidad social. De ahí que Barragán cite textos en los que los artesanos dicen no pretender "ocupar el lugar del magistrado o Coronel» sino el «derecho a aspirar a un mismo puesto teniendo las mismas calidades, es decir, la misma educación», que junto a la moral y a la religión hacen al «hombre moral, al honrado, al trabajador, en una palabra, al buen ciudadano» (17).

(17) Rossana BARRAGÁN, «La época del artesanado culto: la lucha por la educación y la ciudadanía en la ciudad de la Paz (1845-1855)», I Coloquio Internacional, El siglo XIX en Bolivia y América Latina, Sucre, 1994 (versión preliminar), págs. 2-19. 
Al negar la desigualdad social basada en el privilegio y al reivindicar la educación como un elemento organizador del orden y de las jerarquías sociales bajo la premisa de que el trabajo era la fuente de toda riqueza y moralidad, los artesanos estaban retomando los conceptos liberales que les permitían ponerse en pie de igualdad con el resto de la población (18). Aunque la política religiosa y fiscal del gobierno de Sucre expresaba el deseo de destruir las bases de la sociedad corporativa y estamental para reemplazarla "por un Estado nación compuesto por individuos libres e iguales» (19), las autoridades de este

(18) En este sentido resulta conveniente exponer la tesis de Willian $\mathrm{H}$. Sewell sobre el desarrollo de la conciencia de clase del artesanado francés. Este autor dice que con la Revolución francesa el concepto de propiedad se convirtió en el fundamento de la sociedad y el Estado; lo que hizo que la naturaleza y las relaciones entre propiedad y trabajo fueran objeto de amplia especulación. Eso llevó a que la propiedad se ensalzara y protegiera por los poderes gubernamentales, mientras que el trabajo, fuente indiscutida de propiedad, terminó sujeto a los rigores del mercado. El resultado fue que los artesanos se vieron exprimidos desde el punto de vista financiero, amenazados con perdida de estatus y cualificación y carentes de forma legal de defensa colectiva contra las fuerzas del mercado libre. En esas circunstancias buscaron formar nuevas organizaciones colectivas solidarias para promover y mantener lo que consideraban el buen orden y los intereses legítimos de sus oficios. Para subvertir la estructura competitiva del sistema económico y legal recurrieron al flexible lenguaje del régimen corporativo, siendo una de sus formas institucionales las sociedades de ayuda mutua. Sin embargo, lo que para los obreros era una regulación en bien del oficio, era una violación de la libertad individual y de la industria a los ojos de la ley; lo que les obligó a presentar sus reivindicaciones públicas con un nuevo vocabulario, basado en la rétorica de la revolución, que condujese a legalizar lo corporativo. Esa retórica les avalaba como actores legítimos en la escena pública y les dotaba del poder de una lengua omnicomprensiva. Mediante la reivindicación de su trabajo como su propiedad, dejaban de ser meros factores de la producción, convirtiéndose en propiedad de los patronos. Y ya convertidos en pueblo soberano, en productores de toda riqueza podían reclamar la atención del gobierno y las claves gobernantes. En resumen, los artesanos explotaron la ambigüedad del discurso libertad convirtiendo sus corporaciones en asociaciones libres unidas por amistad fraternal y filantrópica, para más tarde transformarlas en cooperativas de productores (William H. SEWELL, Jr., Trabajo y revolución en Francia. El lenguaje del movimiento obrero desde el Antiguo Régimen hasta 1848, Madrid, Taurus Humanidades, 1992, págs. 100, 199, 205-206 y 271-296).

(19) Frederic RICHARD, "Política, religión y modernidad en Bolivia en la época de Belzu», I Coloquio Internacional El siglo XIX en Bolivia y América Latina, Sucre, 1994 (versión preliminar sin notas), pág. 5. 
país no desautorizan hasta la década de 1880 la existencia de corporaciones como los gremios artesanales y las comunidades indígenas. Los imperativos económicos derivados de la construcción estatal y expresados en la necesidad del tributo (20), la inestabilidad política, las distancias y el predominio de lo local rural favorecieron que los principios liberales convivieran con sistemas de autoridad tradicional favorables a comunidades organizadas donde todos y cada uno debía ocupar su sitio, amparados por cuerpos sociales celosos de su autoridad y autonomía, esto es, instituciones sociales que desempeñaban funciones naturales como la familia, la iglesia, las comunas y las corporaciones (21). Esa coexistencia de formas antiguas y nuevas de relación no implicó un conflicto, sino que forzó a la población a reelaborar un entramado de relaciones en el que lo nuevo y lo viejo se intercambiaron significados, contenidos y defensores. A partir de ahí nada volvió a ser exactamente lo que fue, porque su uso o reivindicación lo modeló a partir de nuevas intenciones, intereses, miedos y expectativas en las que participaron todos los grupos sociales (22).

En teoría, la persistencia de una concepción corporativa o comunitaria de lo social hacía que aquél que no perteneciera a uno de esos grupos estuviese fuera de la sociedad bajo la denominación de vago, vagabundo o mendigo (23). En el reglamento de policía del año 1845 se definían como vagos a aquéllos que no se les conocía "oficio, ocupación, destino, bienes, rentas ni modo de vivir honesto» (24). Rossana Barragán indica que en

(20) Víctor Peralta, En pos del tributo. Burocracia estatal, elites regionales y Comunidades indigenas en el Cusco rural, 1826-1854, Cusco, CBC, 1991 y La formación del Estado moderno en Bolivia, 1825-1880, Tesis de Maestría, FLACSO-sede Ecuador, 1992.

(21) Botana [2], pág. 155.

(22) Al respecto son interesantes las tesis de Fernando de Trazegnies sobre la "modernización tradicionalista»; esto es, una modernización capitalista limitada por una profunda resistencia por parte de las elites a modificar las jerarquías sociales tradicionales (La idea del derecho en el Perú republicano del siglo XIX, Lima, Pontificia Universidad Católica del Perú, 1992).

(23) GUERRA [3], pág. 9.

(24) Reglamento de Policía, 10 de junio de 1945. Colección oficial de Leyes, Decretos, Órdenes, Primero de marzo de 1845 al 28 de febrero de 1846, tomo décimo, Sucre, 1863. 
esa situación se encontraban los jornaleros y colonos que no trabajaban todo el año, los romeros y santeros, los adivinos, hechiceros y sorteros, los vagabundos que no tenían domicilio determinado. También estaban próximos a ella los «mal entretenidos» entre los que se encontraban los menestrales y artesanos "desaplicados por vicios y olgazanería», e incluso los oficiales o aprendices cuando eran equiparados a los colonos y domésticos (25). La necesidad de no quedar encuadrado en la categoría de marginal o doméstico y, por tanto, no ciudadano, llevó a que los artesanos hicieran siempre lo posible para demostrar su honradez y buena conducta a través del ejercicio de un trabajo no dependiente. Por esa razón, en los juicios todos los artesanos se presentaban como de un oficio determinado, aunque a veces eso no fuera cierto. Tal acción respondía a que éste daba a la persona un lugar en la sociedad.

La búsqueda de existencia social por parte de los artesanos nos conduce a un tema básico en la discusión sobre la expansión de la ciudadanía: el uso social de la ambigüedad de las normativas democráticas respecto a la definición del ciudadano (26). Este tema remite a lo que ya se ha señalado sobre la imbricación, superposición e interacción de nuevas y viejas prácticas políticas. La ambigüedad de la norma dio lugar a posiciones contradictorias y enfrentadas que reivindicaron por igual y para sí el nuevo discurso político. Así, mientras un sector de la población se servía de una determinada lectura de la norma para excluir a otro de la condición de ciudadanos a través de acusaciones de dependencia y servidumbre, otros peleaban por su reconocimiento como ciudadanos apelando al sentido de dicha norma. En el primer caso se buscaba dotar de legitimidad republicana a los argumentos coloniales de se-

(25) Barragan, [17], pág. 14.

(26) Marcello Carmagnani y Alicia Hernandez sostienen para el caso mexicano que fueron las transformaciones económicas, políticas y sociales acaecidas en el curso de la segunda mitad del siglo xvIII, las que empujaron a la población mestiza, india y mulata a procurarse un nuevo estatus jurídico $y$ social que reconociera su condición de vecino, prerrequisito para poder acceder a mayores privilegios («Dimensiones de la ciudadanía orgánica mexicana, 1850-1910» en el Coloquio Internacional "The Expansión of Citizenship in Latin America», Colombia, 1995 [versión preliminar], pág. 1). 
gregación social. La acusación de «situación oscura y desconocida» que, en el antiguo orden hacía referencia a las castas, pretendía tener validez en el nuevo orden al fundamentar la exclusión del sujeto en su no trabajo, en su dependencia de otro, lo que le convertía en un parásito, luego en un vago no útil al bien social. Frente a esa lógica perversa, nacida del temor a la igualdad jurídica y la convivencia espacial de los criollos con los sectores populares urbanos, la salida que le quedaba al artesano era rebatir a su oponente con la misma narrativa de moralidad y honradez, es decir, admitiendo como válidos a los argumentos de clasificación ciudadana. Es decir, considerando como acertados y necesarios los principios de exclusión presentes en los reglamentos electorales. La necesidad de poseer una existencia social refrendada explica por qué en Bolivia los sectores populares no quisieron eliminar las restricciones de ciudadanía y por qué se esforzaron en coincidir con las nociones morales de notable que implicaban una discriminación étnica en la que todos participaron. La población boliviana aceptó los criterios de exclusión y no buscó transformar la normativa electoral. Prefirió adecuarse en lo positivo a ella pidiendo al Estado que desarrollase las medidas necesarias para obtener ciudadanos. Eso explica que en 1845 se entendiera el fomento de la educación como un deber estatal que conduciría a la ciudanía y al progreso, en contra de opiniones que veían en la situación deficitaria del Estado un impedimento para que éste reglamentase la educación. En definitiva, los artesanos quisieron candidatos y electores letrados, con cualidades intelectuales y morales reconocidas por todos. Y a esa intención se debía la reivindicación del decreto de Bolivar del 11 de diciembre de 1825 que establecía escuelas primarias (27), al igual que su apoyo a Belzu por el restablecimiento del Colegio de Artes y Oficios, institución fundada en

(27) La salud de una república depende de la moral que por la educación adquieren los ciudadanos en la infancia». Decreto sobre el Establecimiento de escuelas primarias y colejios de ciencias en las capitales del departamento, y además de una escuela militar de la República. Decreto 11 de diciembre de 1825. Colección oficial de Leyes, Decretos, Ordenes del Congreso y del Gobierno de la República Boliviana, Sucre 1831, vol. 1. 
1827 como las «Maestranzas de Artes y Oficios» (28). Años más tarde, con motivo de las elecciones de 1917, un miembro del Partido Liberal dio un discurso a los artesanos seguidores de su partido en el que decía que la igualdad de derechos sólo podía adquirirse mediante la generalización de la instrucción, insistiendo en que las agrupaciones obreras debían fomentar escuelas, universidades populares y salones de conferencias:

Entre los planteles de instrucción hay un inmenso vacío, hace falta un Colegio de Artes y Oficios donde el obrero adquiera conocimientos científicos, porque la ciencia es el producto de la verdad... Anexa a esta institución vendría la escuela profesional donde las mujeres con el trabajo aprenden a defender su pudor (29).

Esta propuesta fue denominada «Ley humanitaria de previsión contra las torpes reivindicaciones" e interpretada como «el pequeño tributo que se exige al capitalista en pro del obrero que le ha formado el capital» a fin de evitar transgresiones sociales mayores.

El riesgo implícito en la ambigüedad a la hora de aplicar e interpretar cualquier normativa obligaba a muchos individuos a demostrar ser acreedores de crédito. Para conseguirlo, los artesanos buscaron tener relaciones que les avalaran, porque con ello se validaba su existencia social e individual. Si no se tenían conexiones con los «creditables, creibles y credibles» uno se convertía en desconocido, en cambio, si se tenían, ese sujeto pasaba a ser ciudadano. La necesidad de tener vinculaciones personales con sectores sociales más altos para que fuesen sus fiadores o garantes en detenciones juicios (30), remite a las razones de los artesanos para convertirse en miembros de las clientelas de la elite. La pertenencia a una de ellas les concedía legitimidad, un refugio, una defensa, ser reconocidos como personas serias y responsables, como individuos morales y de bien,

(28) Colección oficial de Leyes, Decretos, Órdenes, tomo undécimo, 1 de marzo de 1846-31 de diciembre de 1846, Sucre, 1863. de 1917.

(29) "La manifestación obrera de mayo» en El Fígaro, La Paz, 10 de abril

(30) BarRagán [17], págs. 15-16. 
en definitiva, como ciudadanos. El puesto que el patrón ocupaba en la sociedad garantizaba que quien fuera avalado por él debía ser tomado en cuenta y respetado. La dependencia del estatus del cliente del prestigio del patrón llevó al primero a ser muy cuidadoso a la hora de escoger señor, lo que, a su vez, provocó un juego de competencias entre futuros patrones para demostrar a sus posibles clientes lo mucho que podían hacer por ellos en virtud de su ejercicio del poder. En contrapartida al prestigio, defensa y prebendas que el patrón daba al cliente, éste tenía múltiples obligaciones entre las que destacaba votar por el patrón o su candidato y movilizar a otros para que lo hicieran.

A medida que las elecciones cobraron mayor importancia, los propietarios rurales se quejaron del costo creciente del aumento material del voto. Si bien la victoria era importante para conservar su prestigio y el apoyo del gobierno, el gran número de dependientes a quienes no podían ocupar en forma productiva y que sólo servían para votar cuando llegaban las elecciones, unido al hecho de que los votantes cada vez exigían mayor compensación, les llevó a negar la ampliación de la ciudadanía. Los argumentos sobre la falta de preparación de éstos, siempre analfabetos, ignorantes e inconscientes, y sobre la consecuente corrupción electoral fueron la solución para reducir el número de posibles electores y de los gastos (31). Sin embargo, el desarrollo en el siglo $\mathrm{xx}$ de una conciencia ideológica y política partidaria o de otras lealtades basadas en lazos de compadrazgo, en la tradición, el odio y la venganza liberó, en cierta medida, a los líderes de pagar el voto, eliminando una de las razones prácticas del sufragio censitario. Asimismo, la presencia de nuevos actores sociales, ajenos a las redes tradicionales de poder, obligó a los políticos a abandonar la práctica de movilizar a los electores sólo en las fechas cercanas a los comicios, sustituyéndola por un ininterrumpido llamado a la participación de estas nuevas fuerzas. Este hecho también modificó las relaciones clientelares; cuanto más se necesitaba la participación popular más continuas.

(31) José Murillo de Carvalho, Desenvolvimiento de la ciudania en Brasil, México, FCE-CM, 1995, pág. 27. 
debían hacerse las prebendas y, por tanto, más rigurosa y profesional la organización interna de los partidos. Éstos se veían obligados a desarrollar nuevas estrategias de captación del voto en sectores tradicionalmente excluidos de la ciudadanía, que a través de la formación obtenida en las escuelas de indígenas desarrolladas en la década de 1920, ingresaban a la vida pública legal, amenazando con ello el equilibrio de partidos. En la media que existía un límite en la capacidad de otorgar prebendas e impunidad a cambio de lealtad, se formaba un grueso de población flotante y descontenta, fuera de las redes de beneficio, capaz de sostener nuevas opciones políticas y trastornar el control autoritario al margen de la ley que existía entonces. A partir de 1900, esa tendencia se vio favorecida con la constitución de la ciudad de $\mathrm{La} \mathrm{Paz}$ en el centro industrial más importante del país, a excepción de las zonas mineras (32). Este crecimiento se produjo gracias a la existencia de trabajadores «emancipados» por la desaparición de las comunidades indígenas urbanas. Pese a ello, su comportamiento político estuvo a veces vinculado a las demandas de restitución de tierras altiplánicas de los caciques-apoderados, lo que muestra que la La Paz no sólo fue un polo de atracción, sino que también formó parte de las estrategias de reprodución campesinas (33).

Si bien el análisis del sentido de los discursos políticos electorales puede revelarnos el modo en que la elite cons-

(32) El "proletario» boliviano estuvo conformado por artesanos, trabajadores del transporte y comunicaciones, de la construcción, gráficos y trabajadores de las industrias manufactureras. Los dos grupos más antiguos fueron el minero y el ferroviario, mientras que el de la construcción cobró dinamismo en las primeras décadas del siglo y el de las industrias manofactureras desde comienzos de la década de los años treinta. En la decada de 1920 aparece en La Paz la industria propiamente dicha con la instación de la fábrica FORNO de tejidos de algodón con 160 obreros. En torno a 1940 había 45 establecimientos por el rubro de Textiles y Vestimentas, 24 ligados a la construcción y 16 a productos químicos y farmacéuticos. En 1944, las industrias paceñas poseían el $64 \%$ del personal empleado en las industrias del país, acaparando el $74 \%$ del total de-la producción.,

(33) Rossana BARRAGán, Espacio urbano y dinámica étnica. La Paz en el, siglo XIX, La Paz, ed. Hisbol, 1990, págs. 229-230; Irma LoRINI, El movimiento socialista "embrionario" en Bolivia, 1920-1939, Cochabamba, ed. Amigos del Libro, 1994, págs. 69-71. 
truyó una narrativa de rechazo de la presencia política popular que fue asumida socialmente como cierta, incluso por los mismos sectores a quienes se despreciaba, a través de esos textos también queda claro que la participación política de los mestizos urbanos fue una realidad que las distintas facciones enfrentadas de la elite propiciaban, a la vez que detestaban. Desde 1825, las alocuciones políticas no sólo hicieron menciones elogiosas o despreciativas sobre los sectores populares urbanos, sino que la mayoría de las veces se dirigían directamente a ellos tanto para indicarles cómo debían actuar públicamente, como para denigrar o valorar esa misma actuación pública (34). Fuera de una manera u otra como les calificaran, siempre se les vio como público activo y movilizable al que siempre se quiso enfrentar entre sí; lo que informa de lo real que fue su ejercicio ciudadano y de su importancia para dirimir conflictos de elite (35). De hecho ante la pregunta retórica sobre dónde estaba «el pueblo o el centro de rotación» que debía mover a «todas las clases de la sociedad» la respuesta dada por los políticos consistía en que «la juventud i los artesanos» se unieran "a las clases activas» para constituir el eje que imprimiera "la dirección conveniente a todos los negocios de interés público» (36).

En suma, aunque el empleo y la participación artesana en el discurso dominante informaba de la gran flexibilidad mestiza e india para acogerse según sus intereses a distintos sistemas de valores o alternativas de moral, eso también condujo a que reprodujesen con otros sectores sociales más marginados que ellos los criterios de exclusión. En el interior de los gremios y entre un gremio y otro existían grados de diferenciación relativos al nivel de independencia económica y laboral del individuo, a su contacto con otros sectores de la población urbana, al destino de su producción, a su condición étnica, a su origen geográfico, a su puesto laboral, a su tiempo de

(34) Sobre las elecciones de 1884 a 1896 véase Marta IRUROzouI, La armonía de las desigualdades. Elites y conflictos de poder en Bolivia, 1880-1920, Cusco, CBC, 1994, págs. 56-72.

(35) El Tiempo, 14 de abril de 1917; La Verdad, 5 de septiembre de 1925.

(36) José PoL, El pueblo y las facciones o la verdadera causa de todos nuestros males, Imp. del Siglo Cochabamba, 1872, págs. 19-23. 
aprendizaje y a la naturaleza permanente o temporal de su trabajo. A eso se sumaba la distribución étnica de los oficios -los de montereros, sombrereros, zapateros, panaderos, carniceros, tejeros y tintoreros correspondían a indígenas- y las diferencias entre artesanos indígenas y mestizos basadas en que los primeros debían pagar 5 pesos anuales como tributo, aunque no tuvieran acceso a tierras (37). El cobro del tributo, además de ahondar las jerarquías del mundo artesano, evidenciaba que al estar las categorías fiscales todavía confusas, contaba más el pasado tributario que el acceso al medio productivo. Eso abre una interrogante referente a si la tributación podía esgrimirse como un argumento para el voto, sobre todo en el caso de los oficiales y aprendices que no constaban como propietarios, o si, por el contrario, el pago de tributo era una prueba de la no calidad moral del individuo para ejercer de ciudadano.

Además estaban las competencias entre artesanos referentes a la disminución del costo y calidad de los productos por parte de los indios emigrados a la ciudad una vez iniciado el proceso de venta de tierras comunales. A finales del siglo XVIII, con el recuerdo de los cercos indígenas de 1781 y 1811 a la ciudad de La Paz, se inició un proceso de adquisición de las tierras de las parroquias-comunidades situadas en el sector rural adyacente a la urbe. Éste se agravó a partir de 1860 con las medidas contra la propiedad de la tierra de los ayllus por parte de Melgarejo (1866-1868), la ley de Ex-vinculación de 1874 y las revisitas posteriores. La penetración de la hacienda y el crecimiento demográfico y físico de la ciudad ocasionaron una escasez constante de tierras para desarrollar actividades agrícolas o ganaderas que llevó a los indios a buscar otras fuentes de trabajo en el artesanado o el comercio. Eso produjo que el oficio se nutriera ya no sólo de las"clases sociales empobrecidas de la ciudad y de los emigrantes de otras provincias y departamentos, sino también de una creciente población indígena sin tierra (38).

(37) BARRAGÁN [7], pág. 21; [33], pág. 113.

(38) BARRAGÁN [33], págs. 121-122, 208-225.

R. I., 1996, n.॰ 208 
Los panaderos eran indios, ya sea de Charapaki; (...) después todos eran del campo; por eso no podían hablar castellano y yo hablaba un poco, cuado llegué ellos me decían: «el mozo». Todos eran jóvenes los de Charapaki, pero migrantes. Tenían su casa en la ciudad, ya que era cerca a sus comunidades (39).

La continua llegada de emigrantes rompía el monopolio ejercido por los gremios, como ocurrió con la existencia de los "obradores», que no tenían licencia ni el seguro que debían dar en fianza al gremio para responder en caso de quejas y demandas. A este problema referente a un aumento de mano de obra que abarataba los productos en detrimento de la calidad, se sumaban las protestas de los Maestros Mayores de los Gremios, que exigieron al gobierno de Belzu el cumplimiento estricto de las leyes que prohibían la importación de bienes del extranjero que perjudicaban a la industria, ya que se culpaba al comercio exterior de favorecer el menosprecio de las obras de los artesanos (40). Las medidas posteriores tomadas a favor del libre cambio por el gobierno de Linares hicieron que la artesanía y las pocas industrias existentes disminuyeran, por considerar que el mayor estímulo que podían tener era "la competencia» y que su atraso se encontraba precisamente en "la exclusiva que ejercen» (41). Si bien la eliminación de privilegios del régimen gremial con la promulgación del derecho a la libertad de trabajo crearon un "artesanado libre", éste buscó conservar las jerarquías de maestros, oficiales y aprendices como expresión de la defensa de su pequeña propiedad y producción (42); no se olvide que el grado de maestro definía la posición del sujeto en la sociedad y en el proceso de producción y cambio:

(39) Leandro Condori Chura y Esteban Ticona Alejo, El escribano de los caciques apoderados Kaskinakan purirarunakan qillqiripa, La Paz, Hisbol/ THOA, 1992.

(40) La Epoca, La Paz, 17 de mayo de 1850.

(41) La Epoca, La Paz, 17 de septiembre de 1845.

(42) Carmen Escobar Rodriguez, La revolución liberal y la protesta del ar. lesanado, Bogotá, Ed. Fondo Editorial Sudamérica, 1990, págs. 17-20. 
En los gremios, la mayor parte ya son provincianos, son campesinos que han desplazado a esa gente que era, se puede decir, el artesanado aristocrático. Ha venido esa corriente, se ha impuesto, y trabajan más barato; trabajan un poco ordinario, pero trabajan en forma artesanal, independiente, y así sucede en el caso de los carpinteros, y especialmente en el de los zapateros y sombrereros (43).

Al colocar al individuo en una situación ventajosa que éste no quería perder, le forzaba también a buscar el modo de conservar su ventaja y eso le llevó a actuar como intermediario entre los partidos políticos y los potenciales votantes artesanos de menor rango. Las cuotas de poder y la protección que los notables de un partido otorgaban al maestro artesano por su labor proselitista y la posición que el mismo adquiría en su comunidad por ser amigo de esos notables eran bienes codiciados por el resto de artesanos a juzgar el modo en que la participación electoral de éstos favoreció la competencia entre partidos. En las elecciones de 1917, que destacaron por el alto grado de competencia alcanzado (44), el Partido Liberal dijo estar apoyado por un artesanado "culto" compuesto por maestros de taller, como es el caso de Rosendo Trino, «de profesión sastre, maestro de taller», que con motivo de una usurpación de su identidad en unas actas electorales declaró que era "un liberal incorruptible» y jamás había "pertenecido al Partido Conservador y menos aún al Partido Republicano por haber heredado los principios liberales que mis padres han sostenido, luchando contra los despotismos de las épocas oligárquicas» (45). En contrapartida, el Partido republicano se vio favorecido por los gremios artesanales más pobres vinculados a la población india y "con adherentes entre algunos comerciantes (judios)»(46). De las agrupaciones obreras liberales se decía que habían desarro-

(43) "Testimonio de José Clavijo», en Zulema LeHM y Silvia RIVERA, Los artesanos libertarios y la ética del trabajo, La Paz, THOA, 1988, pág. 148. 1917.

(44) «Noticias alarmistas o infundadas», El Diario, La Paz, 10 de mayo de

(45) El Fígaro, 1 de abril de 1917.

(46) ¿Quién es el presidente del grupo republicano en Tarija? Por los prestigios de mi tierra», El Diario, La Paz, 1 de mayo de 1917. 
llado un criterio cívico, una aspiración de mejora porque "habían establecido escuelas, ayudando así al Estado a educar a los hijos del pueblo". Ese hecho impedía que se les manipulase políticamente con difamaciones y prebendas en alcohol, como sí sucedía con los obreros republicanos siempre "artesanos descalificados de la peor especie (47), que no tenían "el menor reparo para exteriorizar sus opiniones de forma violenta y asaz agresiva» (48). El diferente estatus artesano que se desprende de la peyorativa y forzada contraposición entre "obrerismo consciente» y "chusma artesana» se ve con mayor claridad en los homenajes a los candidatos presidenciales. Mientras «los obreros del trabajo» (49) liberales, "el elemento de más valor de la clase obrera de La Paz, compuesto por más o menos ciento cincuenta jefes de talleres» ofrecían al candidato liberal Gutiérrez Guerra «una fiesta campestre» (50), los «miembros del pueblo suburbano», "los obreros de la más baja capa social» desfilaban entre "una abigarrada muchedumbre de ex-comunarios de algunos ayllus» y cholas (51). Además, la prensa partidista acompañaba esas descripciones con cifras en las que demostraban cómo el Partido Liberal contaba en sus filas con más maestros de taller que los republicanos (52), ya que éstos eran los únicos que actuaban como "adversarios de guante blanco, leales y caballerescos», con ningún interés «en alterar la serena constatación de la mayoría (53).

La forma en que eran catalogados los seguidores de uno u otro bando evidenciaba también la continuidad del cliché de castas para desvalorizar al contrincante. Esta vez la referencia a un origen "oscuro y desconocido" no se utilizaba para evitar la participación electoral como ciudadanos, sino para descalificar a un partido en virtud de sus simpatizantes. Para los liberales, los manifestantes republicanos no eran ciudadanos porque se

(47) El Fígaro, 13 de abril de 1917.

(48) El Diario, La Paz, 17 de abril de 1917

(49) El Tiempo, 15 de abril de 1917.

(50) El Figaro, La Paz, 3 de abril de 1917.

(51) El Fígaro, La Paz, 10 de abril de 1917; El Tiempo, 19 de abril de 1917.

(52) "Obreros principales de taller», El Diario, La Paz, 4 y 5 de mayo de 1917.

(53) «El país está fatigado», El Diario, La Paz, 2 de mayo de 1917. 
trataba de personas «todas desconocidas», al ser en su mayoría "sirvientes y peones que habitaban en las cercanías de la ciudad» (54). En contraste, los adherentes liberales eran «todos bien conocidos y de espectable situación, es decir, lo mejor que existe en Santa Cruz» (55). El hecho de que entre los primeros "no hubiese una sola persona conocida que pudiera responder de cualquier atentado" (56) mostraba su grado de incultura y por tanto la falta de capacidades de gran parte de los sectores populares para adquirir cualquier responsabilidad política; lo que se reafirmaba al constatarse que entre estas "personas absolutamente desconocidas» habían "más indígenas que ciudadanos» (57). El criterio de parecer o ser "desconocido» remitía a un código cotidiano de discriminación basado en factores étnicos. Esta norma parecía estar en vigencia a juzgar por la acusación de los republicanos a los liberales de haber incumplido las garantías electorales, dado que sólo permitían «el ingreso a la plaza a ciudadanos con cara de ciudadanía». A su vez, la respuesta de los liberales al carácter infundado de esas quejas porque únicamente estaba prohibido «el ingreso de niños y mujeres» (58), mostraba cómo el ser ciudadano excluía a todos los considerados menores de edad y necesitados de tutela -indios y mujeres (59)-, y, por tanto, la vigencia del concepto

(54) «Fracaso de la manifestación republicana», El Diario, La Paz, 2 de mayo de 1917.

(55) «La manifestación Liberal», idem.

(56) «Actos incultos de los republicanos», El Diario, 3 de mayo de 1917.

(57) «El resultado electoral del domingo», El Diario, La Paz, 8 de mayo de 1917.

- (58) Idem.

(59) Aunque las mujeres no son consideradas ciudadanas por su calidad de dependientes del varon, en la literatura de la época se hace una distinción entre la mujer de extracción humilde a la que se cita como «mujer» y se iguala a la categoría de indígena y la mujer de situación acomodada a la que se hace mención como «distinguidas señoras, damas y señoritas de sociedad». Esa diferencia queda más marcada cuando se hace referencia a su forma de participación en las elecciones. Mientras las primeras desfilan junto a los obreros y artesanos dando vítores a su partido, para más tarde agredir a los opositores con piedras, "presas del alcohol y los bajos instintos». Las segundas se sitúan en los balcones para "arrojar flores a los clubes manifestantes». Es decir, unas se involucran en los comicios como fuerza de choque, y otras lo observan.

R. I., 1996, n. 208 
de padre de familia como garante del orden cívico, esto es, de la ciudadanía entendida como vecindad. Pese a ello, cuando un partido descalificaba a otro apelando a un vocabulario de castas, además de remitir a la pervivencia de formas coloniales de sociabilidad, revelaba también cómo la competencia entre partidos generaba una dinámica de participación popular que a la larga terminaría trasformando el concepto vigente de ciudadano. Ya en 1925 se dijo que gracias a la legislación social del Partido Republicano «el obrero es dentro de nuestra nacionalidad un ciudadano que tiene deberes que cumplir y derechos que hacer valer, (que) ha pasado de su calidad de elemento de explotación y de abuso a ser hombre» (60).

El hecho de que los artesanos aceptaran dividirse y participar en una contienda en donde un partido descalificaba a otro haciendo mención al origen social y cualificación laboral de sus seguidores ejemplifica también la necesidad política que tenían del aval de los «notables». No se olvide que en la práctica de la época, la calificación como ciudadanos votantes era otorgada a los artesanos y pequeños comerciantes sin que éstos presentaran ningún documento que demostrase que tenían el nivel de ingreso requerido por la ley. Al no establecer el reglamento la manera en que debían comprobarse éstos, a veces bastaba un comprobante de pago, a través del que se juraba que el votante tenía los ingresos establecidos por ley, o que figurasen en la lista de quiénes habían pagado la patente municipal que requerían para ejercer sus ocupaciones. Como las listas estaban en manos de las autoridades del gobierno local, éstas no dudaban en adecuarlas para facilitar la calificación de los individuos de extracción social media y baja que apoyaban las candidaturas oficiales o cuyos votos podían controlar. Al mismo tiempo podían impedir la inscripción a aquéllos en los que no confiaban o no podían manipular. Ser ciudadano dependía, entonces, de criterios interpretativos aleatorios que implicaban compromisos personales.

A su vez, la indefensión de los artesanos frente al libre mercado y su crecimiento provocaron la aparición de las Socieda-

(60) "El Partido Republicano y el obrero», La Reforma, La Paz, 24 de abril de 1925. 
des de Socorros Mutuos en la década de 1860. La primera entidad de este tipo se organizó en La Paz el 4 de febrero de 1860 bajo la denominación de "Junta de Artesanos» y adquirió personalidad jurídica mediante la Resolución Suprema del 16 de marzo de 1861, durante la presidencia del general José María Achá. La agitación popular desligada de la Masacre de Loreto, el 23 de octubre de 1861, sirvió de excusa para el cese de las actividades de este colectivo, lo que volvió a repetirse en Oruro con la Sociedad de Ártesanos de Socorros Mutuos, fundada el 22 de agosto de 1875. Aparte de los casos citados, no hay noticias de este tipo de organización hasta 1883, después de la Guerra del Pacífico. Entre 1900 y 1930, la mutualidad fue la impulsora del movimiento laboral de los obreros, al tiempo que suplió el vacío estatal relativo a prácticas de asistencia social en el orden médico, financiero y funerario (61). Su presencia política se concretó con la publicación de periódicos, como El artesano honrado (1896) de la Sociedad Obreros El Porvenir de La Paz, fundada el 15 de julio de 1888 (62), y a través del deseo de los partidos tradicionales de emplear a las agrupaciones mutualistas como potenciales votantes y agentes electorales (63). La necesidad de apoyo social popular llevó a los políticos a convertirse en organizadores de mutualidades o en miembros honorarios de prestigio, lo que acerca a estas organizaciones a las clientelas políticas y refuerza una idea, ya mencionada, relativa a la conveniencia de establecer lazos de "amistad" con personas con crédito social (64). Al respecto es también significativo

(61) Aunque la mayoría de las mutuales estuvieron constituidas por artesanos, existieron también en los centros mineros, como fue la Cooperativa de "Aurigas y Obreros», o "Sociedad Mutual Protectora de Mineros de Uncía», LORINI [33], pág. 105.

(62) Marcos Néstor Valenzuela Gutiérrez y Fernando Chuquimia BoniFAZ, La mutualidad boliviana, La Paz, 1995, págs. 1-65.

(63) «La manifestación obrera», El Fígaro, La Paz, 10 de abril de 1917.

(64) La Guardia Republicana de Bautista Saavedra reproduce otro ejemplo de "amistad» definida por una desigualdad étnica. Era un cuerpo "antioligárquico" y "cholo", de amplio respaldo popular, integrado por milicias populares y una fuerza policial paramilitar, cuyo origen estuvo en los «clubs de partidos", que se crearon para proteger a los dirigentes y a la prensa y para disponer de una fuerza de choque en las elecciones (James DuNKERLEY, Orígenes del poder militar en Bolivia. Historia del Ejército, 1879-1935, La Paz, ed. Quipus, 1987, págs. 114-115). 
que la mayor parte de las aprobaciones de estatutos de este tipo de asociaciones se dieran en fechas cercanas a las contiendas electorales (65). Por otro lado, dado que el tipo de relación personal elitista y excluyente, presente en las mutuales, no satisfacía las demanadas sociales de un sector popular urbano en continuo crecimiento e indefenso ante las fluctuaciones del empleo, progresivamente el sindicato cobró protagonismo:

Nosotras hemos dicho que no vamos a ser sociedad mutual (...) en las mutuales, si no estaban de acuerdo, igual tenían que hacer lo que ordenaban. Trataban del trabajo, entre ellos nomás. En cambio nosotros, los sindicalistas, trabajámos para todos; somos más avanzados en la idea (66).

La cita anterior se refiere al Sindicato de Culinarias (67). Al igual que lo sucedido con otros oficios masculinos, existía un esfuerzo por parte de la elite paceña de controlar su acción y someterla a una práctica paternalista. Esto se manifiesta en la actitud que tuvieron algunas socias de la Convención de Señoras, celebrada el 16 de noviembre de 1944, cuando escucharon la reivindicación de que el trabajo de las cocineras fuera reconocido como profesión y reducida la jornada laboral a ocho horas:

Unas nos han felicitado, porque hemos asistido y otras nos han mostrado mal humor de lo que las cholas han venido en medio de las señoras: «a estas señoras del Sindicato no hay que recibirlas porque son ladronas». Ellas estaban en contras de nosotras, no estaban de acuerdo con la organización siempre. Querían que fueran Mutuales (68).

(65) Véase, Anuario de Leyes, Decretos, Resoluciones y Órdenes Supremas, años 1904-1925, ediciones oficiales, La Paz.

(66) Declaración de doña Peta», en Ana Cecilia Wadsworth e Ineke DibBits, Agitadoras de buen gusto. Historia del Sindicato de Culinarias (1935-1958), La Paz, ed. Tahipamu-Hisbol, 1989, pág. 71.

(67) El Sindicato de Culinarias pertenecía a la Federación Obrera Femenina (FOF), fundada en 1927. Sus actividades se interrumpieron con la Guerra del Chaco (1932-1935), volviéndose a fundar con los diversos sindicatos en 1940 y existiendo hasta 1965, aunque después del 52 se unió a la Confederación de Gremiales, de carácter clientelista y vertical, [66], pág. 202.

(68) «Declaración de doña Peta», [66], pág. 111-112. 
Pese a la declaración de independencia laboral, existió entre sus miembros admiración hacia el mundo que les marginaba (69), ya que asumieron que su mejora social pasaba por el contacto y la asimilación de aquellas cualidades que refrendaban a la elite como tal (70). Pero fue justo la admisión de sus deficiencias y de la existencia de valores a los que propender, lo que les posibilitó una futura nivelación social:

Tenemos que culturizarnos, tenemos que ser educadas, tenemos que ser ésto, el otro, defendernos, no dejarnos ultrajar (71).

En suma, la lucha y búsqueda artesanas de un estatus que les hiciera ser reconocidos como respetables por y frente a la sociedad les llevó a aceptar las normativas de exclusión y segregación sociales como válidas y necesarias. Su respeto por las condiciones de ciudadanía implícitas en un régimen censitario era la garantía de su reconocimiento público como personas morales. Y el hecho de asumirse a sí mismos como tales, les obligaba a ver a los otros fuera de los requisitos marcados por las ordenanzas electorales:

Ahora están más bien unidos, pero en esa época: «Indio», nos decían, los criollos nos trataban así; eso no era bueno, sin embargo ahora ha mejorado: "Estos indios, estas indias", decían «los indios», decían, así decían esos mocitos y artesanos. De este modo no había comunicación. Porque esos mistis, querían parecerse a aquellos mistis que llegan de otros países (72).

(69) Ser empleada doméstica es un honor, una honra, porque donde pisa la mejor gente pisamos nosotras. En espejo grande nos miramos la cara", «Declaración de doña Natividad», [66], pág. 191.

(70) Cuando he ido donde mis familiares, me he mirado de pie a cabeza, un desaire único porque me he puesto pollera, porque ya parecía del campo: iay!, nos vas a poner en bajeza, icómo pues!». Declaraciones de doña Peta (Petronila Infantes)» [66], pág. 21.

(71) «Declaración de doña Exaltación» [66], pág. 75.

(72) CONDORI y TiCONA [39], pág. 74.

R. I., 1996, n. 208 
La demanda de ampliación de la ciudadanía hubiera significado reconocer que ocupaban el último lugar en el orden social, que eran iguales que otros grupos sociales marginados que carecían de su especialización y formación como trabajadores. El miedo a una nivelación por lo bajo les llevó a aferrarse a los criterios con que la elite juzgaba su entorno, porque sólo a través de ellos serían gente decente. De ahí que todo su empeño fuera demostrar estar dentro de la ciudadanía o reivindicar fórmulas, como la educación, que les asegurase estar dentro. El haber optado por no cuestionar ni querer cambiar las leyes evidenciaba su respaldo a la lógica de una sociedad jerarquizada. De ahí que este trabajo esté en desacuerdo con que "la sensación de indefensión de los artesanos cultos» les llevase a sentirse cercanos al resto de los artesanos y minimizara sus diferencias internas hasta el punto de crear una conciencia de clase artesana (73). Más bien hubo estrategias de supervivencia social que obligaron a muchos artesanos, en su mayoría maestros, a sacrificar cualquier solidaridad horizontal que no implicase defensa de privilegios y futura movilidad social ascendente. La amenaza a la devaluación del oficio, en vez de favorecer alianzas populares, cerró progresivamente los canales para las mismas. Quizá por ese motivo hubo una progresiva división en el tiempo entre los artesanos, entre aquéllos que formaban parte de las clientelas de los partidos oficiales y aquéllos otros que escogieron las opciones libertarias; y quizá también por ello existió un progresivo rechazo de los intermediarios políticos y una voluntad de negociar directamente con la presidencia (74). Pero pese al respeto a la jerarquía y a la necesidad de discriminación implícitas en el anhelo de movilidad social, el hecho de que la vida política local se midiera bajo nociones de igualdad reforzó la idea de la educación como medida de transgresión de las barreras sociales y de la ciudadanía como medio de expresión de una voluntad popular de presencia y decisión públicas.

(73) BarRagan [17], págs. 23-26.

(74) Nosotras culinarias, en contacto con los patrones -iJay!- ya conocemos sus tretas. Hay que dirigirse al Presidente quejándose de estos brutos que nos vinieron encima». "Grandiosa sesión parlamentaria en el mercado de las cholitas paceñas», Calle, La Paz, 27 de marzo de 1941. 


\section{2. "LA MISERABLE CLASE INDÍGENA»}

La actitud artesana de no exigir el sufragio universal al gobierno, pero sí pedirle instrucción para convertirse en ciudadanos «morales», se volvió a manifestarse con la población indígena, con la diferencia de que las demandas de ésta no pretendían que la educación favoreciera su movilidad social sino la restitución de sus propiedades comunitarias confiscadas desde 1866. Si los primeros comprendieron que la única forma de intervenir en las decisiones gubernamentales era la obtención de una ciudadanía a la que se llegaba a través de la instrucción, los indígenas asumieron que para la reconquista de sus tierras les convendría convertirse en ciudadanos y para serlo pidieron al Estado la creación de escuelas. De nuevo, otro sector asumió los criterios de exclusión censitaria como válidos, reconoció que el analfabetismo limitaba su capacidad política y aceptó como sinónimo de progreso y civilización la educación. Eso implicó también que el voto iba adquiriendo progresivamente valor y era identificado como la forma de adquirir autoridad o de manipularla para obtener beneficios personales y colectivos.

Las decisiones de los gobiernos conservadores y liberales destinadas a terminar con las corporaciones y entidades colectivas, buscaron disminuir el valor de lo local en la definición de la vida pública, lo que afectó directamente a las comunidades indígenas. Si bien ese objetivo abarcaba muchas variables, una de ellas estaba referida al deseo de restringir los márgenes de autonomía política de que gozaban las comunidades indígenas. El texto gaditano de 1812 exigía como únicos requisitos para ejercer el derecho a voto en ámbito parroquial, la vecindad y un modo de vivir honesto y conocido, y consentía «la institución de municipalidades en cada pueblo en que conveniese que hubiera» (75). De esto resultó la proliferación de los ayuntamientos constitucionales de indios, ya que éstos se habían tomado muy en serio la ciudadanía española recién adquirida. Más tarde, las primeras constituciones republicanas volvieron a proponer, aunque de manera más articulada, el requisito gaditano anterior, acompañado de la exclusión de va-

(75) Chiaramonti [7], pág. 7.

R. I., 1996, n.o 208 
gos, mendigos y sirvientes, y continuaron confiando a los notables locales la efectiva selección del electorado. En esta actitud subyacía una explícita voluntad de consentir a los indígenas no sólo elegir, sino también ser elegidos, por lo menos en ámbito parroquial. El requisito de alfabetización, que principalmente los excluía, aunque previsto para el ejercicio del sufragio ya desde la Constitución de 1825 , no se exigió legalmente hasta 1840 e incluso 1861 . Sin embargo, es probable que ese precepto no se aplicara estrictamente con los indígenas comunarios hasta la década de 1880 bajo el argumento de que eran tributarios, como ocurrió en Perú.

En la primera mitad del siglo xIx, el realismo político imponía considerar el hecho de que la población indígena era mayoritaria, sobre todo en el altiplano y en los valles aledaños más productivos. Además, su contribución tributaria ayudaba de modo sustancial a abastecer las arcas estatales (76). El reconocimiento de esa dependencia por parte de las autoridades republicanas garantizaba una relativa autonomía indígena para la gestión de territorio y recursos como parte del pacto de reciprocidad, e implicaba el respeto de las redes de poderes locales, estratégicas para el cobro del tributo y para reclutar mano de obra indígena. Sin embargo, esa situación no se mantuvo. En la Convención Nacional de 1880 se expresaron dos opiniones fundamentales respecto a qué hacer y cómo interpretar judicialmente la tenencia de tierras de comunidad por parte de la población indígena. La primera abogaba por la conversión del indio comunario en colono de hacienda y la segunda apoyaba su transformación en pequeño propietario. Los partidarios del indio colono pensaban que la venta de tierras de comunidad proporcionaría considerables rendimientos agrícolas, «aumentarían el ganado y los productos, cediendo la abundancia en beneficio directo del pueblo menesteroso que compraría más barato los artículos de primera necesidad, a la vez que la renta aumentaría la riqueza social y pública» (77). Se afianzaría

(76) En 1832 el tributo representaba el $45 \%$ de los ingresos del Estado y en 1846 el 54 \% Clara López Beltrán, Biografía de Bolivia. Un estudio de su Historia, La Paz, ed. Juventud, 1993, pág, 115.

(77) APLP. Colección León María Loza, Posesión y ventas de tierras de propiedad indigena. Extracto de opiniones valiosas del Redactor de la Convención 
también el derecho de propiedad, eliminándose las usurpaciones recíprocas y las guerras entre comunarios y hacendados. Al tiempo, las ventas de tierras producirían a la nación unas rentas superiores a las que en ese momento aportaban los indios tributarios, al estar basadas en el valor de la propiedad o de la renta territorial. Por otro lado, se consideraba que estas medidas iban a favorecer a los indígenas mucho más que su conversión en propietarios, ya que no perderían su derecho al pastoreo como sí que ocurriría cuando recibieran lotes de tierras en propiedad. Además, la condición de colono les aproximaría a la sociedad y al trato de "clase ilustrada" venciendo su aislamiento y las "veleidades" criminales provocadas por el medio ambiente del Altiplano. También ganarían la protección del hacendado que les eximiría de las exacciones y pleitos de las que eran víctimas gracias a los lazos filiales que se establecerían entre ambos (78).

Lo que no se decía y estaba implícito en el discurso es que el interés de ver convertidos a los indígenas comunarios en colonos, es decir, en personas sin propiedades, en individuos supeditados y al servicio de un patrón resolvía los dos problemas principales que planteaba el indio comunario. Primero, su peligro subversivo, $\mathrm{y}$, segundo, los términos de su integración nacional. Respecto al primer problema, su resolución se entendía a través de una reforma en la educación del indígena que progresivamente le fuera haciendo válido para la convivencia con la población blanca; es decir, que limitara su agresividad potenciando su capacidad de trabajo. Sin embargo, la instrucción del indio conllevaba el riesgo de transformarlo en ciudadano, de hacer de él un boliviano con voto y decisión; estado que no era aceptado por los sectores dominantes, que interpretaban la presencia ciudadana india como una amenaza a su proceso de reconstrucción aún sin concluir. El problema era entonces ¿cómo integrar al indio al proyecto de reestructuración de elite sin que se compartiese sus derechos públicos? La transformación del indio comunario en colono de hacienda resolvía la

Nacional de 1880, emitidas por los Honorables Convencionales de ese año. Sobre el derecho que tiene el Estado para vender las tierras de comunidad poseidas por los indigenas. La Paz, 1880.

(78) Idem, f. 1 y $9-9 v$.

\section{R. I., 1996, n.o 208}


contradicción de incluir al indígena en el diseño nacional como productor y no como ciudadano, con obligaciones y sin contrapartidas. Su condición de colono asalariado y sin propiedades al servicio del hacendado aseguraba su participación en las tareas agrarias impidiéndole, a su vez, el acceso individual a las urnas y, por consiguiente, a la vida política. Además esa exclusión política, basada en sus preferencias laborales y no en su naturaleza, no invalidaba el discurso a favor de su mejora, que siempre podía ser entendido como posibilidad real aunque ésta no llegara a materializarse.

Ambas opciones abogaban por la transformación social del indio a través de la eliminación del tributo indígena, cuya ejecución le pondría al nivel de los demás ciudadanos. Este hecho evidenciaba que la venta de tierras y la reestructuración del régimen de propiedad era de una importancia social, económica e industrial especialmente provechosa para la expansión y asentamiento de las bases de poder de le elite. Sus diferencias discursivas residieron en razones múltiples que fueron desde la existencia de rivalidades partidarias, de ambiciones de poder que se expresaron en querer monopolizar el bienestar del indígena y controlar, así sus simpatías, hasta motivos básicos como decidir quién se quedaba con la tierra. Es decir, la polémica indio colono versus indio pequeño propietario tenía que ver más con formas de definir la jerarquía, las competencias y la movilidad social en el interior de la elite que con deseos igualitarios o de incorporación nacional.

En 1881 (79), el gobierno de transición del General Narciso Campero implantó, según la ley vigente de 1874, la abolición del proteccionismo estatal respecto a las comunidades indíge-

(79) «La Ley de $10^{\circ}$ de octubre de 1880 , al introducir algunas modificaciones a la ley del 5 de octubre de 1874, que no alteran sus términos fundamentales, establece en su arítculo $4 .^{\circ}$ que: Los indígenas sin tierras quedan eximidos del tributo así como de los servicios oficiales del Estado que han pesado sobre ellos, como de postillonaje, pongueje y otros; quedando sujetos en su caso a todos los impuestos que recaigan sobre la generalidad de los bolivianos. La exención de este artículo, tendrá lugar cobrado que sea el semestre que expira en diciembre próximo» en Rigoberto PAREDES, La altiplanicie. Anotaciones etnográficas, geográficas y sociales de la comunidad aymara, La Paz, ed. Isla, 1965, págs. 170-171. 
nas (80). Ladislao Cabrera, su Secretario de Estado, fue el encargado de aumentar los fondos públicos del Erario nacional. Para ello tomó dos tipos de medidas que afectaron a las tradicionales relaciones entre Estado y sociedad. Primero, aquellos indios que poseían tierras comunales debían pagar su tributo en bolivianos en la misma cuantía que lo habían hecho en pesos mientras esperaban que se efectuase la distribución de títulos de propiedad por parte del gobierno. Pero, en tanto que el antiguo peso constaba de ocho reales, un boliviano equivalía a diez con lo que el cambio implicaba un aumento del $25 \%$ del tributo. Segundo, una vez llevada a cabo la venta de las tierras los propietarios tendrían que pagar de 5 a 50 bolivianos por el título de propiedad. Después de adquirirlos, los comuneros estarían sujetos al impuesto de propiedad pagado por todos los ciudadanos dueños de propiedades, suprimiéndose el tributo (81). Tales medidas iban encaminadas más que a transformar al indio comunario en colono a convertirlo en un pequeño propietario, vulnerable a las arremetidas del mercado y a las presiones de compra de tierras de los hacendados y vecinos de los pueblos. Con ello no sólo se disminuían en un futuro inmediato tanto los conflictos de resistencia indígena a la expropiación agraria derivados de su conversión en colonos, como se evitaban las complicaciones legales de creación de un nuevo status para el indio, sino que también se legitimaban las adquisiciones de los nuevos propietarios y se disponía de un excedente de mano de obra. Una vez sin tierra el antiguo indio de comunidad se vería obligado a emigrar a las ciudades o a trabajar como asalariado en las haciendas y en las minas. De esta forma los dos proyectos expresados en la Convención Nacional se harían posibles complementándose mutuamente, ya que la figura de propietario terminaría convirtiéndose en la de colono, con la ventaja de que su condición no implicaría más hipotéticas obligaciones estatales. Al tiempo, esta conversión habría hecho

(80) Tristan Platt, «La experiencia andina de liberalismo boliviano entre 1825 y 1900: raíces de la rebelión de Chayanta (Potosí) durante el siglo XIX" en Steve STERN (comp.), Resistencia, rebelión y conciencia campesina en los Andes, siglos XVIII-XX, Lima, IEP, 1990, pág. 281.

(81) El Comercio, La Paz, 6 de julio de 1881. 
realidad la expansión de la propiedad hacendaria y habría debilitado la fuerza de la resistencia india debido fundamentalmente al quiebre de su cohesión comunal. Pero estos proyectos de la elite no tuvieron una solución tan fácil, a causa de la oposición-rebelión indígena (82).

El deseo de los sectores dominantes de que no hubiera ampliación ciudadana se combinó con un respeto al sufragio censitario por parte de los sectores populares. Con la ley de exvinculación empezaron a proliferar apoderados mestizos que ostentaban poderes falsos $\mathrm{u}$ obtenido mediante engaños. Eso provocó que la mayoría de documentos de compra-venta realizados después de la revisita de 1881 fueran firmados por estos sujetos sin el conocimiento de los comunarios (83). En vista de ello, los indígenas prefirieron contar con sus propios escribanos para viabilizar sus trámites y escribir los memoriales. Así, hacia 1912, las autoridades originarias articularon organizaciones para emprender nuevamente la lucha legal, que consistía en recuperar las tierras de comunidad a través de los antiguos títulos de composición con la Corona de España, cuya legitimación fue confirmada por la ley de 23 de noviembre de 1883:

Los caciques: "Nosotros no estamos en el partido ¿qué será la política?, ¿qué querrán decir esas cosas?», así decían, «nosotros tenemos títulos, nosotros somos dueños de las tierras y eso somos nosotros: por eso tenemos que defendernos con nuestros documentos». Esas eran sus palabras, ellos no se metían en la política (84).

Como respuesta al esfuerzo de organización indígena, en 1914 apareció el movimiento de los caciques-apoderados. Estos representantes indígenas establecieron la ciudad de $\mathrm{La} \mathrm{Paz}$ como lugar de contacto con los miembros de otras comunida-

(82) Marta Irurozoui, Elites en litigio. La venta de tierras de comunidad en Bolivia, 1880-1899, DDT 54, Lima, IEP, 1993, págs. 9-15.

(83) Carlos B. MAMANI CONDORI, Taraqu 1866-1935; Masacre, guerra y «Renovación" en la biografía de Eduardo L. Mina Ohispi, La Paz, ed. Aruwiyiri, 1991, pág. 29.

(84) Condori y Ticona [39], pág 61. 
des para impulsar formas de lucha y autodefensa legales conjuntas (85). Sus líderes provenían de dos zonas. La primera era de predominio comunario, aunque bajo la amenaza de la expansión latifundista. La segunda abarcaba las regiones más agredidas por la misma, como eran Taraqu, Waki, Tiwanaku y Pukarani. Todos ellos coincidían en la necesidad de hablar y leer castellano para gozar de mayor independencia en sus reivindicaciones y evitar riesgos de malinterpretación de las mismas, de ahí que fuera una referencia constante la petición al Estado de instrucción para el medio rural.

La Constitución de 1880 declaró que la instrucción primaria era gratuita y obligatoria, siendo su atención responsabilidad de los municipalidad, tal como ya decía la "Ley de Libre Enseñanza» del 22 de noviembre de 1872, que buscaba educar a los hijos de "la gente pobre» para "la industria y el trabajo", ya que "enriquecida su inteligencia» volverían a los "talleres de sus progenitores a ejercer el oficio de éstos» (86). Sin embargo, en la práctica, la obligatoriedad no alcanzaba a la población nativa, debido al alcance urbano de las jurisdicciones municipales y a la carencia de recursos económicos. Si bien las principales medidas legislativas fueron dictadas por los gobiernos conservadores (1880-1899), fueron los liberales (1900-1920) los encargados de aplicarlas. Ya en 1900, Gregorio Tito y un grupo de excomunarios de Arasaya y Masaya «y demás parcialidades ubicadas en el cantón Copacabana» se presentaron ante la Cámara de Diputados para pedir instrucción alegando que "si las garantías constitucionales se encuentran excepcionadas de la raza indígena, natural es que el amparo institucional nazca estableciendo en los principales ayllus escuelas que ilustren y mejoren su carácter tímido y desconfiado de las opresiones que hemos venido introduciendo» (87). Durante el primer gobierno de Ismael Montes, después del fracaso de las "escuelas de primeras letras", se establecieron

(85) MAMANi [83], pág. 69.

(86) Gustavo Rodríguez Ostria, Estado y Municipio en Bolivia. La Ley de Participación Popular en una perspectiva histórica, La Paz, Ministerio de Desarrollo y Medio Ambiente, 1995, pág. 43-45.

(87) La raza indígena ante la Cámara de Diputados», El Comercio de Boli. via, 22 de octubre de 1900. 
las primeras escuelas rurales, bajo la modalidad de «escuela ambulante», a las que siguieron las "escuelas fijas» en las comunidades. Ante la falta de preceptores especializados para el área rural se fundó en 1910, en La Paz, la Escuela Normal de Preceptores de Indígenas, instalándose otras Normales en Umala en 1915, en Puna en 1917 y en Sacaba en 1919. La mayoría de los centros educativos creados en este período dependieron las iniciativas económicas de los beneficiados:

Se nota verdadero entusiasmo en algunas agrupaciones indígenas que ofrecen su trabajo gratuito a fin de obtener los rudimentos de instrucción primaria a que pueden unirse algunos conocimientos prácticos de agricultura (88).

Su desarrollo sólo ocurrió en aquellos lugares donde existía menor oposición de los hacendados, ya que éstos interpretaban la alfabetización india contraria a sus intereses porque fortalecía la lucha legal comunitaria por la tierra. En 1920 se crearon escuelas indígenas en cantones de densa población aymara, bajo el lema de que la educación rural no solamente debía alfabetizar, sino también crear en el indio «hábitos civilizados» $\mathrm{y}$ capacitarlo para las labores agrícolas y manuales.

Pese a ello, la instrucción se impartió principalmente a los hijos de los vecinos mestizos, mientras que comunarios y colonos fueron abandonados por las autoridades educativas. Frente a esa situación, Bautista Saavedra emitió su Proyecto de Ley de Alfabetización del indígena como el Decreto Supremo de enero de 1923. Este favoreció a los indios comunarios, pero no así a los colonos de hacienda, que no pudieron hacer nada para que los patrones cumpliesen con las disposiciones estatales (89).

"Los patrones que pongan escuelas», decía. Puso el decreto, pero no pudo cumplir. Los caciques iban a conversar con

(88) Memoria que presenta el Ministro de Justicia e Instrucción Pública ante el Congreso Ordinario de 1900. Escuelas Indigenas, La Paz, 1900.

(89) Humberto MAMANI CAPCHIRI, "La educación india en la visión de la sociedad criolla: 1920-1943", págs. 81-84; Vitalino SORIA CHOQUE, "Los caciques-apoderados y la lucha por la escuela (1900-1952), págs. 49-53 en Educción indigena, ¿ciudadania o colonización?, La Paz, ed. Aruwiyiri, 1992. 
el sr. Saavedra, cuáles serían, pero se entrevistaron. Sin embargo yo no sé decir: «Vamos a hablar», decían (...) De Abdón Saavedra: "Es su hermano», decían. El era perfecto; es decir, la mayor autoridad departamental. Ese Saavedra estaba a favor de los indios. Don Tula (Santos Marka) y Don Willka (Rufino) siempre se entrevistaban; antes los recibían nomás. Ahora ya no es así (90).

En 1931, caciques de La Paz, Oruro, Potosí, Cochabamba y Chuquisaca, en nombre de nueve departamentos de la República solicitaron al ministro de gobierno y justicia garantías para "la elección de alcaldes Mayores y Menores, autoridades indígenas en las provincias y cantones en cada nuevo año". El objetivo de la petición obedecía al deseo de que la educación indígena fuera controlada por los propios interesados con fondos del Estado al ser obligación de los alcaldes la fundación de escuelas en sus ayllus. De este modo, la educación no beneficiaría sólo a los vecinos mestizos. El 19 de agosto de 1936 se dictó otro decreto que disponía que todos los campesinos debían aprender a leer y escribir mediante la creación de núcleos rurales indígenas y el patrocinio de los propietarios de hacienda, que deberían apoyar la educación de sus colonos. Ese decreto quedó en letra muerta:

Es que mis compañeros se han ido al campo a formar escuelas; pensaban que las escuelas deberían ser construidas por los mismos campesinos, escuelas para sus hijos. Ese ha sido el delito; por eso les han traido, a los campesinos y a mis compañeros directo a la cárcel (91).

Hubo que esperar al primer Congreso Indigenal de Bolivia en 1945 para presentar de nuevo el tema de la educación (92). Posteriormente, en el Congreso de Caranguillas de 1947, los campesinos asumieron que la educación no era suficiente y que había que realizar una reforma agraria. En esa fecha se eviden-

(90) CONDORI y Ticona [39], pág. 63.

(91) «Declaración de doña Peta», [66], pág. 171.

(92) Claudia Ranaboldo, El camino perdido. Biografia del lider campesino Kallawaya Antonio Álvarez Mamani, La Paz, SEMTA, 1987, págs. 74-75. 
ció también la dificultad de una alianza minero-campesina y la necesidad del sufragio universal:

Sólo queríamos que sea voto universal para podernos expresar; nunca hubiéramos creido que los políticos sólo se estaban sirviendo de nuestro voto, porque como trabajadores del campo eramos la mayoría. Más tarde, cuando entendimos todo esto, ya no quisimos votar para estos grupos, pero ellos adoptaron el modo de infiltrarse en el campo, buscando compadres, comadres, ahijados y así podernos engañar (93).

De lo anterior se desprende que en todo momento los líderes comunarios percibieron la instrucción como un medio de acceso al conocimiento de las leyes criollas, a la lectura de los títulos antiguos y a todos los trámites de reivindicación de tierras:

«No sabemos leer ni conocemos la lengua en la que está escrita la legislación y sin embargo debemos sujetarnos a ella..., sólo queremos la instrucción de los niños aborígenes para que no sufran lo que nosostros sufrimos» (94).

Los proyectos de educación pedidos por los indígenas no sólo buscaban su "instrucción y alfabetización", sino una educación orientada hacia la defensa de los derechos comunitarios de ayllu, en concreto, la recuperación de tierras. Pero más importante que los contenidos prácticos del proyecto fue que la escuela creó una espectativa de cambio social y cultural entre la masa indígena. Eso se expresó en una transformación de su actitud en las luchas de reivindicación de tierra. Llegó un momento en que la ley ya no les servía como único instrumento de combate, comprendiendo la importancia de ejercer el poder político. Cambiaron de tener capacidad de resistencia, a tenerla de lucha: pág. 170.

(93) "Testimonio de Antonio Álvarez Mamani», en Ranaboldo [92],

(94) Vitaliano Soria CHOQue, "Los caciques-apoderados y la lucha por la escuela (1900-1952)», [89], pág. 59. 
"Civilícense, aprendan a leer y escribir, ya que por no saber leer todos nos abusan, nos quitan tierras, pues nosotros no nos defendemos, ni podemos hacerlo, somos manejados como ovejas» (...) Si hubieran seguido una política, en ese caso hubieran protestado. Ese, pues, hay que tener en cuenta, ya que ellos no seguían una política, por eso: «sólo con la ley podemos hacerlo todo y nada con la política». Porque por una política descuartizaron a Tupaj Katari, en eso yo pensaba: «Hay que unirse y aprender a leer y escribir (...) Leí un folleto; como gente hay que pensar, pero los indios van a seguir equivocándose (...) pienso que la ley oprime. Por ejemplo, para los Mamani, los Condori, los Qhispli están dictadas las leyes y están en vigencia la ley de los viejos criollos, a esas leyes les van a ser jurar, a quienes suban al gobierno, aunque suba el cojito (Jenaro Flores Santos), ya que los criollos gobernaron sus leyes y a eso les van a hacer juramentar: «Bueno, vas a respetar estas leyes» (95).

En suma, la organización india implicó movilización y conflicto y, por tanto, deseo de participar en lo político. Si hasta la década de 1920 se reivindicaba la devolución de las tierras haciendo mención al pacto de reciprocidad entre el Estado y las comunidades indígenas (96), en años posteriores se luchará por el reconocimiento y cumplimiento de los derechos políticos adquiridos a través de las leyes. De ahí su creciente interés en vincular educación con ciudadanía; lo que también derivó hacia una propuesta de autogobierno indio a nivel nacional como muestra Carlos Mamani al decir que el proyecto de Eduardo L. Nina Qhispi consistía en una sociedad multiétnica y pluricultural, bajo un gobierno de mayoría india (97). Este proceso fue bloqueado a partir de la Guerra de Chaco. En la post-guerra, el apoyo estatal al sindicalismo obrero y al campesino en las haciendas, ayudó a desarticular el movimiento indio, lo que se agravó tras la Revolución de 1952 (98).

(95) CONDORI y Ticona [39], págs. 62-63.

(96) Véase Tristan PlatT, Estado boliviano y ayllu andino: tierra y tributo en el norte de Potosí, IEP, Lima, 1978; Estado tributario y librecambismo en Potosi (siglo XIX), La Paz, ed. Hisbol, 1986.

(97) MAMANi [83], pág. 114.

(98) Ramón Conde MAMAnI, «Lucas Miranda Mamani: Maestro indio UruMurato» [89], pág. 115.

R. I., 1996, n.o 208 
Por otra parte, al igual que en el caso de los artesanos, los caciques-apoderados, profesores y dirigentes indígenas buscaron relacionarse y aliarse con personas e instituciones del mundo criollo -políticos, abogados, gremios, sindicatos urbanos y la iglesia católica-; y conectar con otras fuerzas sociales -intelectuales urbanos, partidos políticos y movimiento obrero- con el establecimiento de las consiguientes redes clientelares (99). La necesidad de fortalecer y asegurar el funcionamiento de sus organizaciones frente al clima adverso y a las circunstancias desfavorables les obligó a buscar el apoyo de un gobierno de turno, a simpatizar con éste o presionarle a través de sus adversarios políticos, lo que se tradujo en un determinado comportamiento de los indios alfabetos.

Durante el gobierno de Ismael Montes (1904-1909), el diputado Ramón González buscaba más ciudadanos para inscribirlos como electores en las elecciones generales. Al tener información de que Avelino Siñani alfabetizaba y desarrollaba otras actividades educativas, pensó en los indios alfabetizados como posibles votantes que le favorecieran. Eso motivó su entrevista en Achakachi con Siñani. Como en esa época el campesino analfabeto no tenía derecho al voto, el diputado le propuso pagar a cada votante alfabetizado la suma de dos billetes. Tras consultar con oti os campesinos, Siñani aceptó la propuesta, quedando el hecho registrado en un documento de compromiso, firmado públicamente, para que los ciudadanos campesinos, ya alfabetizados, participaran en las elecciones. La hija de Siñani señala al respecto que su padre «pensó que si aceptaba, era lógico que muchos campesinos pondrían más interés para aprender a leer y escribir, porque cobrarían por sus firmas y podrían, además votar por primera vez en una elección». Avelino Siñani utilizó el voto como un incentivo para que el campesino tomase interés por la instrucción, sin que eso le evitara ver que si las autoridades permitían votar a unos cincuenta alfabetizados, éstos de alguna forma estaban

(99) Vitaliano SORIA CHOQUE, «Los caciques-apoderados y la lucha por la escuela (1900-1952)», pág. 60: Roberto CHOQUE CANQUI, "La escuela indigenal: La Paz (1905-1938)», págs. 25-40, [89]. 
participando en la representación nacional. En 1909 Siñani fue invitado al Congreso por el gobierno de Montes para que siguiera preparando ciudadanos votantes. Él aceptó, pero a cambio no quiso bienes, sino la dotación de un profesor diciendo: "queremos profesor para aprender más y más, para que nuestra patria sea grande» (100).

La continua pérdida de tierras comunales bajo la presión de los hacendados y de los pequeños propietarios mestizos convirtió a $\mathrm{La} \mathrm{Paz}$ en refugio de los indios expulsados miembros del movimiento de caciques-apoderados. Allí no sólo hallaron respaldo en los antiguos ayllus de Chukiyawu, esto es, entre los caciques y maestros mayores de ayllys y gremios indios de San Sebastián, Santa Bárbara y San Pedro (101), sino también entre los miembros de los partidos políticos, en concreto entre la oposición republicana. Dado que la fecha de inicio de las acciones de esa organización indígena, en torno a 1914, coincidieron con la fundación del Partido Republicano y dado también que el ex-presidente liberal, Manuel Pando, había abandonado a sus correligionarios para formar parte de este partido, es posible inferir que sus vínculos con la población indígena aymara fueran heredados por los republicanos y que éstos alentaran la organización indígena como futuro de refuerzo de sus actividades políticas. Además no hay que olvidar que, entre 1901 y 1904, Bautista Saavedra había sido abogado de los indígenas acusados de la masacre de Mohoza (102) -a quienes algunos autores señalan como precursores del movimiento de caciques-apoderados-, y que en 1916, él y su cuñado Max Bustillos defendieron a Santos Marka Tula, Francisco Tanqara y otros caciques, que sufrían persecución y destierro por estar tramitando la matrícula de tierras y la legalización de títulos coloniales de propiedad:

(100) Tomasa SiÑANi DE WILLCA, "Breve biografía del fundador de la 'escuela-aylly': un testimonio escrito sobre Avelino Siñani», [98], págs. 128-129.

(101) SORIA CHOQue [89], págs. 44-45.

(102) Marta IRURozQuI, "La pugna por el indio. Los liberales y la iglesia de Bolivia, 1899-1920" en Gabriela Ramos (comp.), La venida del reino. Evangelización, religión y cultura en los Andes, siglos XVI-XX, Cusco, CBC, 1994, págs. 377-402.

R. I., 1996, n. ${ }^{\circ} 208$ 
Después apareció el republicano por algunos años. «Está a favor de los indios». Los indios se aliaron a ellos. "Republicano» se decía. Eran alabados «El Republicano está a favor de los indios, el liberal no, ellos son patrones». Y era verdad. Se decía Republicano a quien quería ser, eso se sabía, por eso nosotros decíamos: «Ellos están a favor de los indios». Los obreros y otros votaban por ellos. Los otros, los ricos, eran del partido liberal: «Ellos son ricos», se decía. Así se vivía. Sólo existieron durante los patrones, cuando fracasaron ellos, los republicanos y liberales desaparecieron. Sólo estuvieron en esos tiempos. Por ejemplo, hicieron Presidencia por el republicanismo el sr. Pando y después Saavedra: «El señor Pando está a favor del indio, porque es indio», se decía. Así se comentaba. No sé si sería verdad, no se sabía, pero así decían los indios» (103).

Es probable que entre los objetivos de esa acción estuviera el usar a su favor el movimiento de caciques-apoderados contra el Partido Liberal y, así, revivir la estrategia del expresidente Pando de movilizar a la población indígena para fortalecer una opción de partido de la elite y presionar simbólicamente con ella a los liberales en el gobierno (104) como habían hecho ellos con los conservadores en vísperas de la Guerra Federal (1899) (105). De hecho las relaciones establecidas entre republicanos e indígenas prosperaron hasta el nivel de una verdadera alianza en 1919, cuando los caciques, aprovechando un proyecto de ley presentado por Saavedra al Parlamento, introdujeron su pedido de «deslinde general de tierras" entre comunidades y haciendas, buscando revertir el proceso de expansión latifundista. La expectativa generada ante la posibilidad de recuperar territorios usurpados, creó las condiciones para una radicalización de las propuestas comunarias hasta el punto de cuestionar las bases mismas del régimen colonial a que se hallaban sometidas:

(103) CODORI y Ticona [39], pág. 60.

(104) Posiblemente los liberales tampoco permanecieron pasivos a la hora de buscar solidaridades ya que dieron en 1917400 bolivianos como "obsequio para trabajos de la Iglesia Matriz del cantón Ylabaya». (ADLP)/Partido Liberal (PL), Caja núm. 1, 1916-1917.

(105) Marta IrurozouI, "La masacre de Mohoza, 1899: la (re)invención de una tradición», en Revista Andina, núm. 22, Cusco, CBC, 1993. 
¡Bolivianos indígenas! Desde este momento dejaís de ser tributarios. Ya no pagareís contribución por cabeza como bestias. Os traemos la civilización y la libertad de industrias (106).

La seguridad de contar con el apoyo republicano se manifiesta también en que al producirse la Revolución de 1920 hubo cambios inmediatos en los cantones tanto de corregidores como de Jilaqatas de hacienda por los comunarios bajo la consigna indígena de que eran "fieles servidores del anterior régimen». Esa misma expresión volvió a ser utilizada ante el Prefecto como medida para evitar que los vecinos de los pueblos se introdujeran en sus propiedades: "otro individuo a quien denunciamos y que también era esbirro del partido doctrinario». En suma, los indígenas estaban presentando el proyecto de restitución de tierras indias como una forma de apoyo al nuevo régimen en contra de sus enemigos: "La saludable revolución del 12 de julio... la hemos saludado en sentido de que hemos pensado y pensamos que con ella han muerto para siempre las pretensiones latifundistas». De ahí que también se dieran casos como el protagonizado por los comunarios de Ñaqupa, en 1922, que buscaron el amparo del corregidor de Taraqu, Fidel Cerruto, de filiación republicana, contra unos hacendados parientes de Montes (107). En general, durante el gobierno de Saavedra, la rebeldía en las haciendas de los liberales fue genealizada en todos los cantones del departamento de La Paz, especialmente en la región Waki-TaraqTiwanaku; lo que hace pensar tanto en la instrumentación partidaria que el gobierno hizo del descontento indígena, como en la dinámica de participación popular introducida por los enfrentamientos y competencias intraelites.

Esa actitud de búsqueda de un refrendo exterior se manifestó también de cara a la Guerra del Chaco (1932-1936) con la división interna del movimiento de los caciques-apoderados en dos bandos. Mientras uno rechazaba la guerra, otro postulaba la necesidad de participar en ella como un servicio más prestado

(106) La Razón, La Paz, 8 de abril de 1920.

(107) Mamani [83], págs. 48-77. 
al Estado a cambio del que se esperaba un compromiso de respeto para la posesión comunal de sus tierras. Los que tomaron esa opción estuvieron en contacto con los futuros mandatarios German Busch y Gualberto Villaroel para los que trabajaron como intérpretes. Esa tarea les permitió ponerse en contacto con un gran número de soldados analfabetos a los que enseñaron a leer y escribir. En consecuencia, la guerra no sólo posibilitó la comunicación entre los excombatientes para crear futuras organizaciones a nivel nacional, sino que favoreció lazos de amistad entre algunos campesinos y los futuros presidentes de Bolivia bajo la etapa del "socialismo militar». Sin embargo, su actitud parternalista, la oposición de otras facciones de la elite al progreso indio y el hecho de que la mayoría de la población indígena no entendía la importancia de la educación, unido a la vigencia de la idea de que el indio "era inculto, ignorante y necesitaba tutela», impidieron que el campesinado tuviera la misma capacidad de presión que obreros o mineros:

Ya desde el comienzo la política del partido fue de arriba abajo, nunca se llevó de abajo arriba, igual casi a lo que hacía el patrón. Si los campesinos se hubieran organizado desde abajo, el sindicalismo sano hubiera puesto raíces y nadie lo tumbaba, hubiera seguido nomás su lucha (108).

Aunque todavía se desconocen la intensidad y proyección de las relaciones mencionadas, lo importante de ellas es que gracias a su doble carácter, urbano y rural, proporcionaban a los políticos un campo más amplio de acción y comunicación, al margen de los poderes locales que eran los intemediarios tradicionales. Esto supuso un reordenamiento de las fuerzas políticas y una remodelación de los términos en que se construían los lazos clientelares. Asimismo, con esas formas de participación informales la colectividad estaba generando en su seno partidos representativos.

Por último, resulta importante destacar que a través del material documental utilizado se puede afirmar que los líderes indígenas tuvieron conciencia del valor político de la educa-

(108) «Testimonio de Antonio Álvarez Mamani» en Ranaboldo [92]. 
ción, pero esta conducta no fue necesariamente mayoritaria entre el resto de la población india. A juzgar por los comentarios del líder kallawaya Antonio Álvarez Mamani hubo mucha incomprensión, desesperanza, indiferencia y miedo al respeto. En lo relativo al mundo mestizo urbano, se puede hacer una aseveración semejante, dado que fueron los artesanos/as vinculados a las propuestas libertarias los más concienciados políticamente con su presente y futuro ciudadano, aunque éste no pasase por la reivindicación del voto. A través de la historiografía boliviana basada en historia oral se conoce gran parte de las propuestas de cambio social y lucha, pero se desconoce el pensamiento de aquéllos que no fueron líderes, de los que ayudaron a sus patronos para estorsionar, delatar y perseguir a otros campesinos, o de los artesanos que prefirieron pertenecer a los partidos oficiales e incluso trabajar para ellos como matones y agentes electorales. Es decir, se desconoce mucho de ese actuar diario de los sectores populares que no entran dentro de las categorías de lo "heróico", pero cuyo conocimiento aportaría información muy valiosa sobre la construcción diaria de la ciudadanía. De ahí que además de mostrar cómo actuaron las elites artesanas-mestizas y campesinasindígenas, sea importante rastrear la acogida, interpretación y representatividad colectivas que tuvieron sus esfuerzos, así como la oposición y recelo que despertaron.

\section{Conclusiones}

La demandas indígenas y mestizas al Estado de difundir la educación primaria o los esfuerzos artesanos por demostrar que sus oficios no les convertían en domésticos buscaron el medio y el reconocimiento de pertenecer o estar integrados en las categorías que los reglamentos electorales señalaban como aptas para ejercer el sufragio. Ese empeño popular por visibilizarse como ciudadanos muestra cómo la participación restringida no significaba que la población careciese de nociones sobre los derechos de los ciudadanos y los deberes del Estado. Sobre todo porque en los regímenes censitarios existieron otros modos de participación menos formalizados, externos a los mecanismos de representación. Esto lleva a plantear el pro- 
blema de la democracia bajo dos nociones que implican aprendizaje: cultura política y "transición» política. Ambas ideas definen la democracia como una experiencia vital, un proceso dinámico, en construcción a partir de la apropiación e interiorización de un determinado comportamiento político; con lo que la democracia se entiende más como una práctica que como un discurso, sin que se pueda prescindir de su interacción. Resulta erróneo pensar que pueda aprenderse a ejercer los derechos políticos sin una práctica continua y un esfuerzo permanente de difusión del discurso democrático. La comprensión del fenómeno gradual de la formación de la ciudadanía requiere el análisis de las maneras formales e informales de participación, ya que es en el juego entablado entre legalidad e ilegalidad donde reside la dinámica de apropiación de la cultura política y, por tanto, la incorporación del individuo a la ciudadanía.

Por ello, aunque la instauración de la democracia en Bolivia no siguió un proceso evolutivo de reformas que afectaron y alteraron progresivamente el armazón constitucional y el juego político imperante, tampoco puede afirmarse que su democratización resultase de la Revolución de 1952 (109). La continua infracción de las leyes y reglamentos electorales creó una cultura electoral donde el voto, comparado o no, tuvo un papel creciente en la difusión del orden político, porque permitía una ampliación práctica del electorado. Y aunque esto habla de experiencias políticas que han dado mayor peso a la participación que a la representación de la sociedad (110), el acto mismo del sufragio llevó a la interiorización de las posibilidades de la representación democrática.

This article analyses the motives and strategies of the Bolivian popular sectors, mestizo craftsmen and indigenous peasants, aiming at achie-

(109) Robert DAHL, Polyarchy, New Haven, Yale university press, 1971, págs. 40-41.

(110) A. Touraine, La Parole et le sang: Politique et Societe en Amerique Latine, París, Editions O. Jacobs, 1988. 
ving social existence as well as public and political presence in a restric: ted election regime (1826-1952). In order to be considered citizens, they did not ask for suffrage extension but demonstrated they had the qualities requested by a system of "learned" vote., making recourse both to the ambiguity of the law and to the dominant political rethoric which made education and citizanship inseparable.

R. I., 1996, n.o 208 